\title{
To Update Ideas, to Explore New Model of Financial Managemen
}

\author{
Pengfei Zhao \\ School of accounting, Zhejiang Gongshang University, Hangzhou, China. \\ Email: zpfyy123@sina.com
}

Received 2013

\begin{abstract}
With the reform and opening up of china, and the globalization of economy, Chinese enterprises are facing more and more complex financial environment, especially since 2008 financial crisis, the government's macro-control, the relative appreciation of RMB, rising labor costs and other non-financial constraints factors, have greatly changed the financial management content, objectives, theory, methods, and ways of working etc, enterprises financial management are suffering from a huge challenge. This paper analyzes the main problems of Chinese enterprises in financial management, and gives some suggestions to work out these problems.
\end{abstract}

Keywords: Financial Environment; Financial Ideas; Change; Explore

\section{Introduction}

In face of the turmoil in financial markets, the continuation of crisis, the increasing difficulty to grasp the policy, the increasingly fierce market competition and the relative appreciation of the RNB, enterprises, especially SMES, are having a difficult operation condition. Difficulties in financing, funding constraints and even funding strand breaks are some of the biggest challenges for SMES, and in Zhejiang province, the problem is more serious, many private enterprises are involved in the whirlpool of usury difficult to extricate, some owners had to leave enterprise to escape liabilities, even to suicide, and more to survive hard. Looking from financial management, many drawbacks exist in the traditional financial management system, including operation models of fund and supervision means etc, and lead to weak financial management functions, now, financial ideas, management models, as well as management tools all needed to be improved[1]. How to accommodate the complicated situation, to get rid of the shackles of traditional philosophy, and explore new financial management model to comprehensively improve the financial fund management level will be related to an enterprise's survival and development. This paper analyzes the current situation in the corporate finance management, and points out the main problems in financial management, finally, the paper gives some suggestions to improve financial management.

\section{Some Factors of Affecting Financial Management at Present}

With the deepening of china's reform and openness, the business environment has improved in the last few decades, but still facing serious challenges. In particular, since the 2008 financial crisis, the turmoil in financial markets, the world economic depression, the relative appreciation of RMB, and the National macro-control policy, have made many enterprise fall into an unprecedented predicament. And the most concentrated difficulty is financing. Specifically, four aspects affecting enterprise financial management is shown as follow:

\subsection{On Environmental in Financial Management}

The environment will bring an important impact on financial management, and always restrict financial activity[2]. Nowadays, the financial management environment is quite complex, both positive and negative, the following is some example, but not only:

1) The turmoil in financial markets, to grasp the macroeconomic policy hard, and to finance difficultly. Some companies were forced to seek the support of the civil usury with great venture, which can not get the normal bank loans, and fall into the position out of risk control;

2) Increasing risk and Financing costs. When domestic monetary was tightened, capital became a scarce resource, the capital cost will rise up significantly, and business risk and investment risk will also increase. 
3) Business environment is getting worse. The obstacles faced by enterprise is not only the above-mentioned financial constraints, there are some non-financial constraints, such as power shortages, government regulation, high tax burden, the underground economy competition and corruption. In addition, recruitment is increasingly difficult, the rising labor costs and the relative appreciation of RMB make enterprises profit margins more narrow, and even fall into unprecedented difficulties;

4) On the contrary, IT and knowledge economy creating opportunities for enterprise development. IT applications can enhance enterprise management level and increase market opportunities, and knowledge-based economy is conducive to enterprises to reduce the technology gap with other enterprises, and even to occupy up the market opportunity first.

\subsection{On Content in Financial Management}

1) On investment decision-making. Reform and opening up bring both opportunities and challenges. Since the 2008 financial crisis, the volatility in international financial markets is frequently severe, and it is becoming more and more difficult to know market. Financial risk exists in everywhere, including foreign exchange risk, interest rate risk, inflation risk and debt default risk etc, even if the sovereign debt, no exception; In addition, the impact originating from political risk and changes risk in legal and policy in the international environment can not be ignored also. Risk and return is always co-existed, and the various risks are always interlaced. So, When china's enterprises go abroad to get more opportunities, we should pay attention to the risks as far as possible[3].

2) On financing decision-making. Overall, the financing channels are getting increasingly rich, but different channels always have different risks. So, companies should finance reasonably and operate the funds. To high-tech industries and information industry, as the representative of the knowledge-based enterprises, the GEM market, venture capital funds will become the most important fund sources. Financing difficulties may be a long-term problem for SMEs, but in any case, financing risk must be cared for.

3) On daily operation of funds. As the world economy's uncertainty increasing, companies will face more intense competition in the domestic and international market. The enterprise's day-to-day production and business activities are directly affected by working capital turnover. Corporate finance department should co-ordinate the budget widely, and attached great importance to the day-to-day operations of funds to adapt to domestic and international competition.

\subsection{On Financial Objectives, Theories and Methods}

1) Low-carbon and emission reduction to protect environment has become a global consensus, and will bring a profound impact on economic development. As a precondition for enterprises to seek to maximize shareholder wealth, the financial management objectives should considered how to fulfill the protection of the environment, to ensure the quality of products and services, and how to support public welfare undertakings. Therefore, enterprises should attach great importance to its financial relationships with, including the shareholders, creditors, suppliers, government, employees and customers etc, based on sincerity. Enterprises should finance timely, adequate, moderately and use these funds effectively.

2) Globalization will make financial management theorieso more open and more technical. Corporate financing management would be taken into account not only to improve the capital structure, but also to improve the internal structure of equity capital and debt capital. With the rise of knowledge economy, intangible and human capital investment will play an increasingly important role in Enterprise Investment Management.

3) A large number of special financial management business and financial approach are originated from the rise of Cross-border mergers and acquisitions etc. These special services, including mergers and acquisitions financial management, the enterprise group financial management and multinational financial management, bring a constantly challenge to the theorists and practitioners, which need them make an unremitting hard exploration[3].

\subsection{On Financial Management Way and Organization}

1) IT has greatly affected corporate financial management. IT makes financial officers to get rid of the tedious day-to-day work towards a more proactive way of working, such as forecasting, analysis of decision-making and exception management. In an open economic environment, capital movement will gradually separate from material movement, and financial management will take the initiative to dominate the reproduction process, and guide enterprises to provide products and services to meet the needs of market. Enterprises should schedule funds to support all types of investment at any time based on market so as to maximize the assets income and increase the value of the enterprise.

2) Financial management and accounting are interrelated but with different functions. When enterprises developed to certain stage, Finance and Accounting Department should be set up separately, and further, the 
Finance Department is divided into fund-raising, investment, financial settlement and other departments to process various types of financial information timely and accurately. Financial management would be run through the entire process of business activities independently instead of the accounting subsidiary.

\section{The Main Problems in the Financial Management in the Current}

China's enterprises has constantly improved financial management with the growth in the reform and opening up, but need to be cool-headed. There are still many problems in the day-to-day financial operations: the "old" financial concept, the virtual financial budget management, the loose fund settlement, the weak supervision system, the low-level management way and means, and low efficiency of fund use, so it is difficult to adapt to the modern financial environment for enterprises.

\subsection{About the "Old" Financial Concept}

The special history and background of China's enterprises determine that the operation mode and enterprise philosophy is subject to certain constraints, the corresponding financial personnel ideas needs to be improved. In developed countries, capital management has become the basic ideas and methods of modern corporate finance, but it is still a relatively new concept in china, and it will be a long process to shift from production operation to capital management. Capital management is different from product management, commodity management and asset management, but a capital-oriented approach, mergers, acquisitions, and restructuring are regarded as the main ways of the capital management. Capital management is continuous process that started from the capital rising, and in turn through the use of capital, the circulation of capital flow and capital appreciation to capital income distribution. Finance staffs should have global and system awareness to co-ordinate capital to better serve the development of enterprises.

\subsection{About the Virtual Financial Budget Management}

Budget is an important function in financial management, however, a considerable number of enterprises have not yet establish the budget management system. Some enterprises have built their budget systems, but it has not been seriously implemented in the production and business activities; Some enterprises lack unified planning and control to the revenues and expenditures, sometimes, even the funds of production and operation is arbitrary changed to engage in long-term investment, and result in cash flow imbalance and lack the ability to pay for. Some enterprises budget is unrealistic and unscientific on ac- count of lack of stringent measurement standards and assessment ways, so the cost constraint is weak. The budget system must have a matching control, assessment, analysis, and incentive etc measures.

\subsection{About the Loose Fund Settlement and Weak Supervision System}

Fund is the blood for enterprises, the strict financial control and scientific, reasonable financial management can enable the businesses to operate orderly. Otherwise, enterprises can not run smoothly. Some enterprises can not control the cash flow orderly because lack viable assessment methods, pre-control fatigue, and the weak audit oversight, some corporate don't know subsidiaries position, including investment and financing information, receipt and expenditure of funds, external guarantees etc contingent liabilities, and profits allocation etc, so they always make the investment decision arbitrary and incomplete, and lead to less effective use of funds. It can better adapt to the financial management, service, or even to guide the business to establish and improve financial control system.

\subsection{About the Low Efficiency of Fund Use}

How to co-ordinate effectively funds within the group companies of enterprise groups, is worth serious consideration. A useful attempt is to set up internal bank or specialized financial company. For most enterprises, low efficiency of fund use or payment difficulty is due to lack of fund use plan and budget, or idling funds[4].

\subsection{About the Low-level Management Way and Means}

IT has penetrated into all aspects of business management. Financial management, as one of the core content of enterprise management, is also influenced no exception. Internationally, 80 percent of the global top 500 enterprises have built their own enterprise management system regarding financial Control as the core. More than 90 percent of users think they have greatly enhanced management efficiency and competition in market. Although IT has been widely used in domestic enterprises, most companies are still stuck at the accounting level difficultly to reflect dynamic operations and not fully meet the information application customization needs in Internet age, so the breadth and depth as a management function need to be improved in china.

\section{Countermeasures to be Taken in the Current Corporate Financial Management}

Globalization has led to fierce market competition. Fi- 
nancial management is playing an increasingly important role in enterprise management, some of the traditional financial management system, capital operation mode and supervision means are facing serious challenge. In order to improve the corporate financial fund management and information system, many companies' financial fund management philosophy, management models, management tools and methods need to be explored and improved.

The author believes that enterprises can try to strengthen financial management from the following areas according to the current situation and characteristics in China:

\subsection{Financial Fund Management would be Determined as the Core of Enterprise Management}

First, financial management idea should be changed, and then attaches great importance to the role of enterprise financial funds management in the production and operation. As an economic system, enterprise is essentially a cash circulatory system - Enter cash $\rightarrow$ outflow of cash $\rightarrow$ inflow of cash $\rightarrow$ outflow of cash $\cdots$, Financial management objectives are tightly bound to be strengthened with corporate strategic objectives, and a series of regulation regarding the financial fund management as the core of enterprise management should be set up to ensure and promote enterprises to strengthen the financial fund management work. Fragmented, inefficient for widespread use and other outstanding issues in the enterprise funds management process need to be improved:

1) Centralized funds management. Started from funds centralized management, it means internal settlement center system should be established, improved and promoted to strengthen the unified management of funds to play better the role of monitoring, services and transfers fund surplus and deficiency. The fact indicated that both the internal bank and the internal financial company have been proved to be a good institutional arrangements and improved capital efficiency.

2) Implementation of comprehensive budget management system. To protect the orderly flow of funds, enterprises should establish and improve the overall budget management mechanism. Budget preparation, analysis and assessment should been implemented in all aspects of Production and operation activities, and regard the budget as the statutory basis of the internal organization, and all income and expenditure of fund will be brought into strict budget management.

3) Confirming the core of cash flow in enterprise management. Monitoring, analysis and forecasting to different categories cash flow need to be strengthened. Enterprises need limit strictly the capital expenditures without budget, and the implementation of large sums of money must be tracked and monitored. Putting and recovery of funds would be maintained in a virtuous circle as possible. In accounts receivable management, raw materials and inventory management, equipment acquisition and management, these work need to be arranged well so that company can better coordinate the relationship among liquidity, safety and effectiveness

4) Companies should establish strict internal supervision and control system to preserve the corporate assets and ensure true and reliable accounting information reported. Accountant assignment system can be tried to make a chief financial officer, the chief financial officer and accountants to play better the supervisory role to prevent the occurrence of asymmetric information and internal control problems; not only would the internal audit system be established and strengthened, but also would be tried to play the role of internal management better from the "post-supervision" to advance forecasting and real-time monitoring, this will help enterprise to ensure the realization of production operation goal, economic interests not violated, and eliminating distortion of financial information.

\subsection{To Establish Financial Concepts of Capital Management}

Modern corporate finance has two specific goals: The first goal is to improve the financial situation of enterprises. Financial sector implemented the financial functions by financing, investment management etc, and make enterprises get stable source of funds and reasonable asset structure so as to sustain their own survival and development. The second objective is to achieve financial benefits and capital appreciation. The core of capital appreciation is how to increase the return on capital.

1) Management of capital stock

Management objective of capital stock is to make the existing capital used well and gain the potential economic benefits fully, which come from resource stock not fully utilized - idle capital and low capital utilization. Enterprises can gain revenue by sale, restructuring and leasing these assets.

2) Management of Capital increment.

Management purposes of Capital increment lie in: First, to optimize the scale of business economies, for this, enterprises should properly handle the relationship between capital investment and economies of scale to avoid blind expansion of investment; second, to accelerate technological transformation and innovation to gain technological progress revenue, for this, enterprises must correctly handle the relationship between income and risk; Finally, enterprises must improve project feasibility study to reduce unnecessary risks. 
3) Management of capital allocation

The capital allocation is the core issue of capital management, and its purpose is to enhance the economic benefits by resource allocation. Two problems will be thought in resources allocation: the first question is how to allocate resources to maximize the output in certain resources; the second question is how to configure the resources to put into the smallest under certain output. In addition, from the perspective of corporate equity, how to optimize the structure of liabilities and owner's equity also belongs to the scope of capital allocation management.

4) Management of capital gains

Capital management is a cycle, often starting in fundraising, and ending in income distribution; capital gains management is an important part of capital management, both the focus and also the starting. Capital gains management consists of three processes: process management, performance management and distribution management. The process management mainly includes price management, revenue management, cost management and process management; the performance management includes profit management, profitability management and capital gains appraisal system; the distribution management includes distribution standard, distribution policy, distribution modes etc. at this stage, Corporate finance should focus on exploring the performance evaluation and compensation of operators, equity management style and distribution form.

\subsection{To Build Management Information System Based on IT}

Application of information technology has become the basic premise for enterprises to participate in global market competition. Informatization is an inevitable trend; building compatible information system platform will make enterprises to achieve financial information and business process integration. The most advantage of management information system is curing regulation and achieving information integration and data sharing among financial system and sale, supply, production systems, and also makes budgets, billing, and monitoring standardization, and ensures the flow of funds, logistics and information flow placed under surveillance. Construction of informatization is a gradual accumulation process for step-by-step, enterprises should study the implementation of program systematically according to their own circumstances. At the beginning, enterprises should choose the right financial management software to carry out financial and business integration to improve the efficiency of funds and avoid financial risk, when condition are ripe, gradually introduce ERP system based on Internet technology to realize the full enterprise information management system.

\subsection{To Improve the Overall Quality of Financial Officers}

In market economy, enterprise competition is ultimately the talent competition. The primary task to improve financial management is to comprehensively improve the overall quality of financial staff. Information technology has set the financial staff free from the daily tedious work, and the center of financial staff work has been shift from the traditional day-to-day management to abnormal, exceptional control and advance prevention, so the professionalism and knowledge structure of the finance staff need inevitably to be raised. In addition traditional financial theory, methods, skills and professional ethics, financial officers should grasp data processing and analysis technology and familiar with more management theory and methods. So, financial and accounting staff needs continually to be trained, and the implementation of the lifelong education system is an important guarantee to comprehensively improve the quality of financial and accounting personnel.

\section{REFERENCES}

[1] W. Z. Liu, How to Do the Chief Financial Officer, Democracy and Construction Press, 2010.11

[2] H. B. Li, Financial Management, Lixin Accounting Publishing House, 2005.1

[3] M. Wu. On Corporate Finance Issues after China's Accession to the WTO,

http://www.govyi.com/n3/paper/m/200602/40764.asp, 2006.2.24

[4] J. H. Ceng, Analysis of Guangdong Private Enterprise Financial Management Problems in Post-crisis Period, Caikuiyanjiu, 2010.7. 